\title{
The Effect of Bilinguality on L3 Breadth of Vocabulary Knowledge and Word Reading Skill
}

\author{
Zohreh Kassaian \\ English Department, Faculty of Foreign Languages, University of Isfahan, Iran \\ Email: zkassaian@yahoo.com \\ Saeedeh Esmae'li \\ English Department, Faculty of Foreign Languages, University of Isfahan, Iran \\ Email: saeedeh.3@gmail.com
}

\begin{abstract}
The present study aims at comparing the performance of bilingual EFL students with monolingual EFL students on vocabulary knowledge test and word reading skill test. 30 Armenian-Persian bilinguals and 30 Persian monolinguals participated in this study. The participants were homogeneous in terms of sex (they were all female), nationality (they were all Iranian), age (17-18 years old), and level of instruction (lower intermediate). Nation's Vocabulary Levels Test was used to measure the breadth of vocabulary knowledge and the Burt Word Reading Test was used in order to measure the participants' word reading skill. The results of the data analyses showed that bilinguality is highly correlated with breadth of vocabulary knowledge and reading skill. In other words, bilingual participants have larger size of vocabulary knowledge and they enjoy better word reading skill. The results are interpreted to have implications for EFL methodologists and syllabus designers.
\end{abstract}

Index Terms—bilinguals, monolinguals, breadth of vocabulary knowledge, word reading skill, learning

\section{INTRODUCTION}

Many people believe that it is difficult to learn a second or foreign language. Bilingualism, however, is common in some parts of the world (to mention just a few examples: North Wales and Welsh-English; Canada and French-English; and places where there are many ethnic minorities within a culture). Reich (1986) had mentioned that $47.3 \%$ of the world's population speaks more than one language. Later, Trask (1999) had reported that 70\% of the earth's population is thought to be bilingual or multilingual. However, the number of bilinguals is increasing in recent years. It is estimated that over 380 million people speak English as their first language; 100 million people use it fluently as a foreign language. As a rough estimate, 1000 million or one billion people around the world have some knowledge of English, either as a native language, as a second language, or as a foreign language (Maghsoudi, 2008).

Bilingualism means different things to different people. For some, it means an equal ability to communicate in two languages. For others, it simply means the ability to communicate in two languages, but with greater skills in one language. In fact, it is more common for bilingual people, even those who have been bilingual since birth, to be somewhat dominant in one language (Maghsoudi, 2008). If a person is fluent in two languages, then the person is said to be bilingual (Harley, 2008). Therefore, bilingualism means having the ability to speak two languages. However, there is a difference between ability and use of language. Someone may be quite competent in two languages, yet rarely or never use one of those languages. Such a person has bilingual ability but does not behave bilingually. A different case is a person who regularly uses both languages, even though one language is still developing. Such a person may be hesitant in speaking, finding it difficult to speak with correct grammar or unable to use a wide vocabulary. Practically, that person may be bilingual, although ability in one language is lacking, but improving steadily. Such a distinction between ability in a language and use of a language shows why the simple label bilingual hides a complex variety beneath its simplicity. Asher and Simpson (1994) had defined bi/multilinguality as the presence and use of two or more languages in a modern nation or state.

Some authorities (for example, Bialystock, 2001, as cited in Harley, 2008; Gleason, 2005) had distinguished between productive bilingualism, i.e. speakers can produce and understand both languages; on one hand, and receptive bilingualism, i.e. speakers can understand both languages, but have more limited productive abilities; on the other hand. Children who had high exposure to a second language throughout their lives, but have had little opportunity to use the language would fall in this category, i.e. receptive bilingualism. When they enter preschool or kindergarten, these children are likely to make rapid progress in second language, English for instance, because their receptive language skills in English has been developed (Gleason, 2005).

There are, in addition, three types of bilingualism based on when the second language (L2) is learned relative to the first language (L1). They are simultaneous bilingualism (L1 and L2 learned about the same time or in other words, learning two languages as first languages. By school age, the two languages are mastered and are completely unique. 
Therefore, the child is able to speak both languages fluently, early sequential bilingualism (L1 learned first, but L2 learned relatively early, in childhood. As a result, children who acquire a second language before puberty are likely to speak it with a native accent, and late bilingualism (from adolescence onwards) (Bialystock \& Hakuta, 1994 as cited in Harley, 2008; Gleason, 2005).

The early theories suggested that bilingualism is harmful. Jesperson (1922), for instance, mentioned that "the brain effort required to master the two languages instead of one, certainly diminishes the child's power of learning other things which might and ought to be learnt" (p. 148). Accordingly, because of the storage of two linguistic systems in the brain, an individual's cognitive capacity and thought are limited and less efficient (Lambert, 1990 as cited in Matlin, 1994: 321). Some other researches (Anastasi \& Cordora, 1953; Darcy, 1953; Printer \& Keller, 1922; Saer, 1923 among others) supported the idea that bilingual children suffered from academic retardation, were socially maladjusted, and had lower IQ comparing to monolingual children. Printer and Keller (1922), for instance, reported a linguistic handicap in bilingual children. In addition, Saer (1923) spoke of mental confusion to describe bilinguals' cognitive functioning. Mattes and Omark (1984) claimed that bilingual children are more prone to stuttering.

In contrast to these claims, some researches in the 1970's and 1980's showed that bilingualism influences the child's cognitive and social development positively (Ben-Zeev, 1977; Bialystock, 1986; Cummins, 1976; Diaz, 1985; Feldman \& Shen, 1971; Ianco-Worall, 1972; Segalowitz, 1977). These studies had shown that bilinguals have superior metalinguistic skills and a more awareness of the arbitrary relationship between vocabularies and their referents. Segalowitz (1977) suggested that the internalization of two languages will result in a more complex mental calculus which enables the bilingual child to alternate between two systems of rules in the manipulation of symbols. In addition, Bialystock (1986) proposed that bilingual children have better control of the linguistic processing needed for metalinguistic problems.

A number of researches (Cummins, 1979; Eisentein, 1980; Hoffman, 2001; Klein, 1995; Lerea \& Laporta, 1971; Ringbom, 1985; Sanz, 2000; Thomas, 1988; Valencia \& Cenoz, 1992; Zobl, 1993) had shown that bilingualism affects learning a foreign language positively. Eisentein (1980), for example, found that learning a second language during childhood would affect learning a foreign in adolescence positively. As another instance, Thomas (1988) compared the acquisition of college French by English monolinguals and English-Spanish bilinguals. The results showed that bilinguals outperformed the monolinguals. She concluded: "Bilinguals learning a third language seem to have developed a sensitivity to language as a system which helps them perform better on those activities usually associated with formal language learning than monolinguals learning a foreign language for the first time" (Thomas, 1988, p. 240). As a result, it has been hypothesized that early bilingualism helps the child analyze distinctive structural properties of alternative language systems (Klein, 1995).

As a whole, based on a large literature, Matlin (1994) had proposed:

"In addition to gaining fluency in a second language, bilinguals seem to have a number of advantages over monolinguals:

1. Bilinguals actually acquire more expertise in their native (first) language. For example, English-speaking Canadian children whose classes are taught in French gain greater understanding of English language structure (Diaz, 1985; Lambert et al., 1991).

2. Bilinguals are more aware that the names assigned to concepts are arbitrary (Bialystock, 1987, 1988; Hakuta, 1986). For example, monolingual children cannot imagine that a cow could just as easily have been assigned the name, dog.

3. Bilingual children are more sensitive to some pragmatic aspects of language. For example, English-speaking children whose classes are taught in French are more aware that when you speak to a blindfold child, you need to supply additional information (Genesee et al., 1975).

4. Bilinguals also perform better on tests of nonverbal intelligence that require reorganization of visual patterns and on concept formation tasks that require mental flexibility (Peal and Lambert, 1962)" (Matlin, 1994, p. 322).

Contrary results of researches on the benefits and drawbacks of bilinguality encouraged some researches (Barik \& Swain, 1978; Lambert \& Tucker, 1972; Nayak et al., 1990; Magiste, 1984) to conduct researches with more controlled variables. Barik and Swain (1978), and Lambert and Tucker (1972) had conducted experiments in which sex and age were considered as control variables. They did not find any significant difference between monolinguals and bilinguals in terms of their intelligence, mental development and school achievement. As another example, Balke-Aurell and Lindbad (1982, as cited in Magiste, 1984) conducted a research on immigrants of varied L1s and Swedish as L2 who were learning English as a foreign language. They found no difference between bilinguals and monolinguals in English comprehension and grammar performance. In addition, Nayak et al., (1990) comparing monolinguals', bilinguals', and multilinguals' acquisition of an artificial grammar, reported that multilinguals showed superior performance under certain conditions over monolinguals. Keshavarz (2004) conducted a research on Turkish-Persian bilinguals, ArmenianPersian bilinguals, and Persian monolinguals in order to investigate their performance on a controlled productive ability vocabulary test. The results showed that native speakers of Turkish and Armenian who speak Persian as their second language performed better in English vocabulary test than the Persian monolingual learners of English.

As Goldman et al. (1984) and Malakoff (1988) had mentioned one of the most important assumptions underlying the efficiency of bilingual instruction is the transfer of skills and learned knowledge from L1 to L2. Goldman et al., (1984) 
found that bilingual children use similar comprehension strategies when listening to Aesop's fables in two languages. Malakoff (1988) also found similarity in performance on analogical reasoning in French-English bilingual children in Switzerland. Therefore, a child learning about velocity in Spanish, for example, should be able to transfer this knowledge to English without having to learn the concepts, as long as the relevant vocabulary (in L2) is available. As a result, having the content knowledge already available in L1 seems to facilitate the learning of the appropriate vocabulary items in L2 (Keshavarz, 2004). Given that skills transfer across languages, it is possible to think about transfer as occurring on a specific, skill-by-skill componential basis, or, more globally, where the entire structure of skills in a domain transfers as a whole (Keshavarz, 2004). If skills do transfer from one language to the other, we could expect the transfer of sub-skills such as vocabulary and word reading skill from L1 to L2.

Third language acquisition may be considered as a relatively young discipline in the field of applied linguistics (Maghsoudi, 2008). However, growing research on the topic signals out relevant differences between second and third language acquisition and it also posits peculiar features to third language learning processes. Accordingly, Clyne (2003) states that learning a third language may share some characteristics with second language learning but in the former case processes are far more complex. In fact, as argued by Cenoz (2000), second language acquisition needs to be distinguished from third language acquisition, as the latter relates to extending the linguistic system of an individual not only quantitatively, but also qualitatively. Following this view, Herdina and Jessner (2002) argue for a dynamic perspective in studying multilingualism phenomena. According to these authors, learning a third language promotes the arousal of new skills and techniques deriving from the learners' previous language-learning experiences.

In many second or foreign language teaching situations, reading receives a special focus. There are a number of reasons for this. First, foreign language students often have reading as one of their most important goals. They want to be able to read for information and pleasure, for their career, and for study purposes. In fact, in most EFL situations, the ability to read in a foreign language is all that students ever want to acquire. Second, written texts serve various pedagogical purposes. Extensive exposure to linguistically comprehensible written texts can enhance the process of language acquisition. Good reading texts also provide good models for writing, and provide opportunities to introduce new topics, to stimulate discussion, and to study language (e.g., vocabulary, grammar, and idioms). Reading, then, is a skill which is highly valued by students and teachers alike (Richards \& Renandya, 2002).

Vocabularies are the primary carriers of meaning (Vermeer, 2001); and as a result, they can be considered as an important part of any language teaching program. Many researches now advocate that learners should initially be taught a large productive vocabulary of at least two thousands high frequency words (Jeanette S. Decarico as cited in CelceMurcia, 2001: 287). Meara (1995), for example, maintained that students should learn very large vocabularies when they start to acquire a language. On the other hand, a number of researches such as Laufer (1997), Hu and Nation(2000) also emphasized that for certain groups of students, a base of two thousand words will be inadequate. Laufer (1997), for instance, had shown that a learner needs to know over 3,000 word families or about 5,000 individual word forms in order to achieve $95 \%$ coverage of words in academic text, and this was regarded as a threshold for minimum comprehension. More recent researches, however, report that learners need to know 98-99\% of words in a written text for sufficient comprehension (Hu and Nation, 2000) which means they must know 8,000 to 9,000 word families in order to be able to read a variety of texts in English (Nation, 2001).

\section{THE PRESENT STUDY}

As vocabulary size and ability to read are very important in learning a foreign or second language, the present study, aims at investigating the relationship between bilinguality of foreign language learners and the breadth of their vocabulary knowledge (how many words a learner knows) and word reading skills. Therefore, the following research questions and null hypotheses are formulated:

1. Is there any relationship between bilinguality of English learners and the size of their vocabulary knowledge in English?

2. Is there any relationship between word reading skill and bilinguality of English learners?

3. Does bilinguality of English learners affect the size of their vocabulary knowledge in English?

4. Does bilinguality of English learners affect the learners' word reading skill?

H1. There is no relationship between bilinguality of the English learners and the size of their vocabulary knowledge in English.

H2. There is no relationship between word reading skill and bilinguality of English learners.

H3. Bilinguality of the English learners has no impact on the size of their vocabulary knowledge in English.

H4. Bilinguality of the English learners does not affect their word reading skill.

Most of the previous studies, except Keshavarz (2004), had focused on European languages. Therefore, the significance of the present study is that it involves two non-European languages, i.e. Armenian and Persian, and it investigates the effect of these languages on English vocabulary size and word reading skill which to the best of researchers' knowledge had not been conducted earlier. The results could shed light on the issue of bilingualism and L3 vocabulary learning and reading skill. 


\section{A. Participants}

In order to control sex and age variables, only female students of the same age participated in this study. Two groups of female students at two different pre-university centers (30 students in each group) of Esfahan (Iran) participated in this study: Group A (Armenian-Persian bilinguals) studying both languages academically; and Group B (Persian monolinguals). The participants were selected randomly from two different pre-university centers. The bilingual participants of this study, i.e. Armenian-Persian bilinguals live in Jolfa district, the south-west of Esfahan. They learn Armenian as their L1 and they learn L2, i.e. Persian in childhood. As a result and according to Bialystock and Hakuta (1994), they can be considered as early sequential bilinguals. Also as they study both languages academically and can use and understand both languages, according to Bialystock (2001) they can be considered productive bilinguals. However, their dominant language is Armenian and in their district they use their L1 to communicate with others.

The participants in both groups were homogeneous in terms of socio-educational context: socio-economic level, type of school attended, methodology used at school, their level, and number of hours devoted to teaching of English. It also should be added that the educational system in Iran is centralized; as a result, the textbooks and methodology for teaching English as a foreign or second language are the same nationwide. However, in order to select the lower intermediate students, Oxford Placement Test was used.

\section{B. Instruments}

The materials used in the present study were as follows:

\section{Oxford Placement Tests (OPT)}

The Oxford Placement Tests (OPTs) provide teachers with a reliable and efficient means of placing students at the start of a course. The tests have been calibrated against the levels system provided by the Common European Framework of reference for languages: Learning, Teaching, Assessment (commonly known as CEF), which has been adopted by the Association of the Language Testers in Europe (ALTE) as well as by governments and major institutions, including exam boards, throughout Europe. The OPTs can clearly and reliably identify any learner's level and also provide a score which will show where the learner is within that band. They can also discriminate levels above and below CEF scale.

The OPTs have been calibrated against a range of major international language examinations and can thus be score of valuable information for learners and course providers with regard to suitable course books and examination targets, e.g. IELTS, TOEFL, TOEIC and others such as Cambridge ESOL Main Suite exams, CELS and BEC, which are explicitly linked to CEF and ALTE levels.

The OPT consists of listening and grammar sections. The listening section consists of 100 items. It takes approximately ten minutes to complete the listening test. Test-takers are asked to choose the correct word which they hear in short sentences from two choices. The grammar section consists of 100 items. Fifty minutes are allotted for completion. Test-takers are asked to read the stem with a blank and to choose one of the three options for the blank. Two sample test items of the vocabulary part are provided below:

a. In warm climates people (like, likes, are liking) sitting outside in the sun.

b. If it is very hot, they sit (at, in, under) the shade.

The grammar part of the OPT was used to choose the students of the same level. Since none of the students were able to reach advanced or expert level, the lower intermediate-modest users were selected for this study.

\section{Vocabulary Levels Test (VLT)}

This is a test of receptive knowledge of English vocabulary, originally developed by Nation (1983), and updated and validated by Schmitt et al., (2000) which is used to measure learners' size of vocabulary knowledge.

Version 1 of this test which has been updated by Schmitt (2000) and used in the present study is composed of five parts representative of five different vocabulary size levels, namely, the 2,000 word-family level, the 3,000 word-family level, the 5,000 word family level, the University Word List level, and the 10,000 word family level. The words in each level of the test have been selected in a way so that they would represent all the words at that vocabulary level.

At each vocabulary size level are ten items, each item comprising six words and three definitions. The test-taker is required to match the three definitions with three of the six words by writing the corresponding number of the word beside its definition. A sample test item is provided below:

1. Business

2. Clock

3. Horse

4. Pencil

5. Shoe

6. Wall

The VLT only tests content words and not function words. The definitions are written using words from the previous vocabulary size level, and the words in each group belong to the same part of speech. The purpose of this restriction is to avoid giving test-takers a clue as to the meaning of a word based on its form. In scoring, each word correctly chosen is awarded one point. Since there are 5 levels, and each level contains 30 correct choices, the maximum score is 150 . 
However, because of the difficulty of the vocabularies for pre-university students, only the 2,000 word-family level and the 3,000 word-family level had been used in this study in order to measure the learners' size of vocabulary knowledge. Therefore, the maximum possible score is 60 .

\section{The Burt Word Reading Test}

The Burt Word Reading Test is an individually administered test. The test is aimed at assessing word-recognition skills. The test consists of a list of 110 words, arranged in groups of ten, and presented in increasing order of difficulty. This version of the test was developed using the results from a representative sample of 2200 children in Scotland in June 1974. Participants are asked to read this list of words. Responses are scored either right or wrong. Each participant's raw score was used for the analysis. The instructions of this test which had been stated in the test manual are:

1. Each student should be tested individually.

2. The test should be taken in a place which is quiet and free from distractions.

3. The student should start at the top of the page and read the words from left to right.

4. The test should continue until the student has made ten (10) errors in succession.

\section{Procedure}

Data collection was carried out in three sessions. In session 1, the OPT was administered to the students. The test was used to choose the lower intermediate-modest users. In session 2, VLT was administered to the learners as a group in their classrooms in order to measure the participants' breadth of vocabulary knowledge; in the third session, the Burt Word Reading Test was individually administered. In this session, each student was individually tested in a private room and the instructions in the test manual were strictly observed.

\section{Data Analysis}

After the administration of the tests, they were scored by the researcher and the results were submitted to statistical analysis. Regarding the first and second research questions, i.e. the relationship between bilinguality of the participants and the size of their vocabulary knowledge as well as word reading skill, Bivariate Correlation was used. Since correlation analysis is used to describe the strength and direction of the linear relationship between two variables, in order to investigate the cause and effect relationship between the variables research questions three and four were formulated. Considering the third and fourth research questions, i.e. the impact of bilinguality of the participants on the size of their vocabulary knowledge as well as word reading skill, independent-sample T-test was used.

\section{RESULTS}

The relationship between bilinguality and breadth of vocabulary knowledge (as measured by Vocabulary Levels Test), was investigated using Pearson product-moment correlation coefficient. Table 1 and Figure 1 show the results of this analysis to answer the first question. As can be understood from Table 1, there is a highly positive significant correlation between the two variables, i.e. bilinguality of the subjects and the breadth of vocabulary knowledge [ $\mathrm{r}=.812$, $\mathrm{n}=60, \mathrm{P}<.01]$. Figure 1 also shows the highly positive significant correlation between the two mentioned variables.

TABLE 1.

CORRELATIONS BETWEEN BILINGUALITY AND VLT

\begin{tabular}{|ll|l|l|}
\hline & & VLT & Linguality \\
\hline VLT & Pearson Correlation Coefficient & 1 & $.812^{* *}$ \\
& Sig. (2-tailed) & & .000 \\
& $\mathrm{~N}$ & 60 & 60 \\
\hline Linguality & Pearson Correlation Coefficient & $.812^{* *}$ & 1 \\
& Sig. (2-tailed) & .000 & \\
& $\mathrm{~N}$ & 60 & 60 \\
\hline
\end{tabular}

**. Correlation is significant at the 0.01 level (2-tailed). 


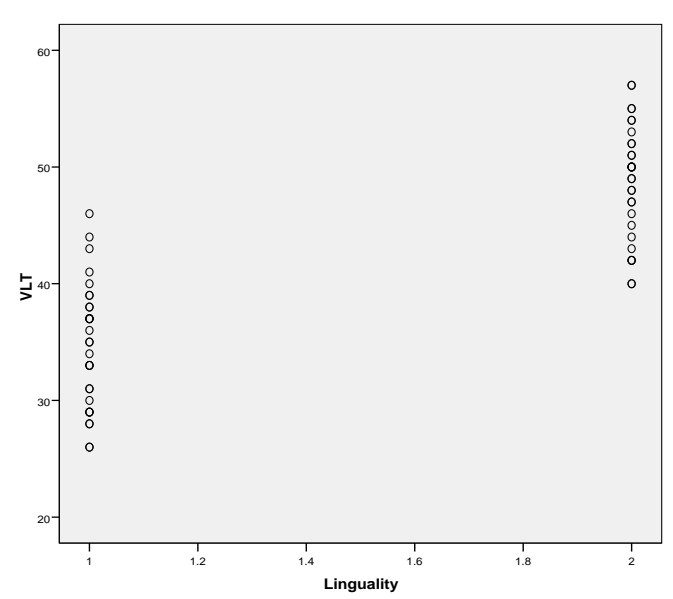

Figure 1. Scatter Diagram Correlation between VLT and bilinguality

The relationship between bilinguality of the subjects and word reading skill (as measured by the Burt Word Reading Test), was investigated using Pearson product-moment correlation coefficient. Table 2 and Figure 2 show the results of the mentioned analysis to answer the second question. Table 2 reports that there is a strong positive correlation between the two variables, i.e. bilinguality of the subjects and the word reading skill $[\mathrm{r}=.885, \mathrm{n}=60, \mathrm{P}<.01]$. Figure 2 also shows this strong positive correlation between the two aforementioned variables.

TABLE 2.

CORRELATION BETWEEN BILINGUALITY AND BURT TEST

\begin{tabular}{|ll|l|l|}
\multicolumn{5}{l}{ CORRELATION BETWEEN BILINGUALITY AND BURT TEST } \\
\hline \multicolumn{1}{|l|}{} & VLT & Linguality \\
\hline Burt Test & Pearson Correlation Coefficient & 1 & $.885^{* *}$ \\
& Sig. (2-tailed) & & .000 \\
& $\mathrm{~N}$ & 60 & 60 \\
\hline Linguality & Pearson Correlation Coefficient & $.885^{* *}$ & 1 \\
& Sig. (2-tailed) & .000 & \\
& $\mathrm{~N}$ & 60 & 60 \\
\hline
\end{tabular}

**. Correlation is significant at the 0.01 level (2-tailed).

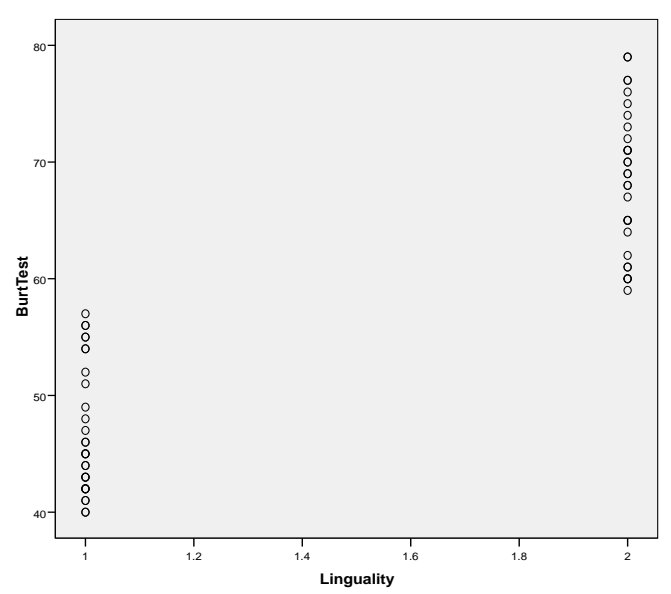

Figure 2. Scatter Diagram Correlation between Burt Test and bilinguality

An independent-samples t-test was conducted to compare the breadth of vocabulary knowledge scores for bilinguals and monolinguals. Tables 3 and 4 show the results of the mentioned analysis for the third question. There was a significance difference in scores for bilinguals $(M=48.77, S D=4.911)$ and monolinguals $(M=34.73, S D=5.349)$. The magnitude of the differences in the means was very large (eta squared=.66).

TABLE 3.

\begin{tabular}{|c|c|c|c|c|c|}
\hline \multicolumn{6}{|c|}{ GROUP STATISTICS (LINGUALITY \& VLT) } \\
\hline Ling & & $\mathrm{N}$ & Mean & Std. Deviation & Std. Error Mean \\
\hline VLT & $\begin{array}{l}\text { Monolingual } \\
\text { Bilingual }\end{array}$ & $\begin{array}{l}30 \\
30\end{array}$ & $\begin{array}{l}34.73 \\
48.77\end{array}$ & $\begin{array}{l}5.349 \\
4.911\end{array}$ & $\begin{array}{l}.977 \\
.897\end{array}$ \\
\hline
\end{tabular}


TABLE 4.

INDEPENDENT SAMPLES TEST (LINGUALITY \& VLT)

\begin{tabular}{|c|c|c|c|c|c|c|c|c|c|c|}
\hline & & \multicolumn{2}{|c|}{$\begin{array}{l}\text { Levene's Test for } \\
\text { Equality of Variances }\end{array}$} & \multicolumn{7}{|c|}{ t-test for Equality of Means } \\
\hline & & \multirow[t]{2}{*}{$\mathbf{F}$} & \multirow[t]{2}{*}{ Sig. } & \multirow[t]{2}{*}{$\mathbf{t}$} & \multirow[t]{2}{*}{ df } & \multirow[t]{2}{*}{$\begin{array}{l}\text { Sig. (2- } \\
\text { tailed) }\end{array}$} & \multirow[t]{2}{*}{$\begin{array}{l}\text { Mean } \\
\text { Difference }\end{array}$} & \multirow[t]{2}{*}{$\begin{array}{l}\text { Std. Error } \\
\text { Difference }\end{array}$} & \multicolumn{2}{|c|}{$\begin{array}{l}\text { 95\% Confidence of } \\
\text { the Difference }\end{array}$} \\
\hline & & & & & & & & & Lower & Upper \\
\hline VLT & $\begin{array}{l}\text { Equal } \\
\mathrm{V} \\
\text { assumed }\end{array}$ & .331 & .568 & -10.58 & 58 & .000 & -14.033 & 1.326 & -16.68 & -11.37 \\
\hline & $\begin{array}{l}\text { Equal } \\
\text { V not } \\
\text { assumed }\end{array}$ & & & -10.58 & 57.58 & .000 & -14.033 & 1.326 & -16.68 & -11.37 \\
\hline
\end{tabular}

An independent-samples t-test was conducted to compare the word reading skill scores for bilinguals and monolinguals. Tables 5 and 6 show the results of the aforementioned analysis for the fourth question. There was a significance difference in scores for bilinguals $(M=68.60, S D=6.078)$ and monolinguals $(M=46.93, S D=5.521)$. The magnitude of the differences in the mean was very large (eta squared=.78).

TABLE 5.

GROUP STATISTICS (LINGUALITY \& BURT TEST)

\begin{tabular}{|ll|l|l|l|l|}
\hline Linguality & & $\mathrm{N}$ & Mean & Std. Deviation & Std. Error Mean \\
\hline Burt Test & Monolingual & 30 & 46.93 & 5.521 & 1.008 \\
& Bilingual & 30 & 68.60 & 6.078 & 1.110 \\
\hline
\end{tabular}

TABLE 6.

INDEPENDENT SAMPLES TEST (LINGUALITY \& BURT TEST)

\begin{tabular}{|c|c|c|c|c|c|c|c|c|c|c|}
\hline & & \multicolumn{2}{|c|}{$\begin{array}{l}\text { Levene's Test for } \\
\text { Equality of Variances }\end{array}$} & \multicolumn{7}{|c|}{ t-test for Equality of Means } \\
\hline & & \multirow[t]{2}{*}{$\mathbf{F}$} & \multirow[t]{2}{*}{ Sig. } & \multirow[t]{2}{*}{$\mathbf{t}$} & \multirow[t]{2}{*}{ df } & \multirow[t]{2}{*}{$\begin{array}{l}\text { Sig. (2- } \\
\text { tailed) }\end{array}$} & \multirow[t]{2}{*}{$\begin{array}{l}\text { Mean } \\
\text { Difference }\end{array}$} & \multirow[t]{2}{*}{$\begin{array}{l}\text { Std. Error } \\
\text { Difference }\end{array}$} & \multicolumn{2}{|c|}{$\begin{array}{l}95 \% \text { Confidence } \\
\text { of the Difference }\end{array}$} \\
\hline & & & & & & & & & Lower & Upper \\
\hline Burt Test & $\begin{array}{l}\text { Equal } \\
\mathrm{V} \\
\text { assumed }\end{array}$ & .155 & .695 & $-\overline{14.45}$ & 58 & .000 & -21.66 & 1.499 & -24.66 & -18.66 \\
\hline & $\begin{array}{l}\text { Equal } \\
\text { V not } \\
\text { assumed }\end{array}$ & & & - & 57.47 & .000 & -21.66 & 1.499 & -24.66 & -18.66 \\
\hline
\end{tabular}

\section{DISCUSSION AND CONCLUSION}

According to the results shown in Table 1 and Figure 1, one can understand that there is a positive significant correlation between the bilinguality of the subjects and the breadth of their vocabulary knowledge. In other words, the bilingual subjects have larger vocabulary size than their monolingual counterparts. Thus the first null hypothesis stating that there is no relationship between the bilinguality of the subjects and the size of their vocabulary knowledge was rejected.

Furthermore, results shown in Table 2 and Figure 2 report a positive significance correlation between word reading skill and bilinguality of the subjects. Therefore, bilingual subjects enjoy better word reading skill than monolingual subjects. As a result, the second null hypothesis stating that there is no relationship between word reading skill and the bilinguality of the subjects was rejected.

Based on Tables 3 and 4, and according to the magnitude of the differences in the mean, it is clear that bilinguality of the subjects has a high effect on the size of their vocabulary knowledge. The third null hypothesis stating that bilinguality of the subjects has no impact on the size of vocabulary knowledge, therefore, was rejected.

In the same way, by referring to Tables 5 and 6 , and the magnitude of the differences in mean, the effect of bilinguality on the word reading skill could be understood. Thus, the fourth null hypothesis stating that the bilinguality of the subjects has no impact on the word reading skill was rejected.

In other words, based on the results of the data analyses the bilinguality of the subjects is correlated highly and positively with L3 breadth of vocabulary knowledge as well as L3 word reading skill. Furthermore, the subjects' bilinguality has a positive effect on L3 breadth of vocabulary knowledge alongside L3 word reading skill. 
The results of the current study reject the early theories of bilingualism which considered subjects' bilinguality as a harmful phenomenon and believed that bilingual children suffered from academic retardation (Anastasi \& Cordora, 1953; Darcy, 1953; Printer \& Keller, 1922; Saer, 1923). In fact the results of the present study are in line with the previous studies which have shown that bilingualism results in more efficient foreign language learning (cf. Lerea $\&$ Laporta, 1971; Cummins, 1979; Eisenstein, 1980; Ringbom, 1985; Thomas, 1988; Valencia \& Cenoz, 1992; Zobl, 1993; Sanz, 2000; Hoffman, 2001; Keshavarz, 2004; Maghsudi, 2006).

The bilingual subjects in this study, i.e. Armenian-Persian students, learned L1 and L2 both academically and orally. They had performed better than monolinguals on Vocabulary Levels Test and the Burst Word Reading Test. This finding is in line with Thomas' (1988) claim that bilinguals had developed sensitivity to language as a system and therefore, would perform better on third language activities than monolinguals. The results are in line with Goldman's (1984) and Malakoff's (1988) claim that skills and learned knowledge from L1 transfer to L2.

As the bilingual subjects of the present study are considered as early sequential bilinguals, the results of the study support Eisenstein's (1980) findings who stated that learning L2 in childhood, would affect L3 learning in adolescence.

\section{IMPLICATIONS, LIMITATIONS, AND SUGGESTIONS}

This study has practical and theoretical implications in language teaching. The results showed that bilingualism has a positive effect on L3 breadth of vocabulary knowledge and L3 reading skill. Therefore, this study provides a basis for improving the quality of practices in the teaching of first, second, and third languages' vocabulary and word reading skill.

However, the number of the participants of the study was very limited and this could affect the result. The study was done considering one grade of the students, as well. Also only two levels of vocabulary levels test were used in this study which may affect the results of the study.

Others can do this study with more students from different grades. This research also can be done with male students. It would be better to have more bilingual groups or work on other skills and sub-skills.

\section{REFERENCES}

[1] Anastasi, A. \& Cordova, F. (1953). Some effects of bilingualism upon the intelligence test performance of Puerto Rican children in New York City. Journal of Educational Psychology 44, 1-19.

[2] Asher, R. E., \& Simpson, J. M. (1994). The Encyclopedia of Language and Linguistics. Oxford: Pergamon Press.

[3] Barik, H.C. and Swain, M. (1978). A longitudinal study of bilingual and cognitive development. International Journal of Psychology 11, 251-263.

[4] Ben-Zeev, S. (1977). The effect of bilingualism in children from Spanish-English low economic neighbourhoods on cognitive development and cognitive strategy. Working Papers on Bilingualism 14, 83-122.

[5] Bialystock, E. (1986). Children's concept of word. Journal of Psycholinguistic Research 15, 13-32.

[6] Carroll, D.W. (2008). Psychology of language. Canada: Thomson Wadsworth, a part of The Thomson Corporation.

[7] Celce-Murcia, M. (2001). Teaching English as a second or foreign language. United States of America: Heinle \& Heinle.

[8] Cenoz, J. (2000). Research on multilingual acquisition. In J. Cenoz, and U. Jessner (Eds.), English in Europe: The acquisition of a third language (pp. 39 - 53). Clevedon: Multilingual Matters.

[9] Clyne (2003). Dynamics of language contact. Cambridge: Cambridge University Press.

[10] Cummins, J. (1976). The influence of bilingualism on cognitive growth: A synthesis of research findings and explanatory hypotheses. Working Papers on Bilingualism 9, 1-43.

[11] Cummins, J. (1979). Linguistic interdependence and the educational development of bilingual children. Review of Educational Research 49, 222-251.

[12] Darcy, N. T. (1953) A review of the literature on the effects of bilingualism upon the measurement of intelligence. Journal of Genetic Psychology 82, 21-57.

[13] Diaz, R.M. (1985). Bilingual cognitive development: Addressing three gaps in current research. Child Development 56, 13561378.

[14] Eisenstein, M. (1980). Childhood bilingualism and adult language learning aptitude. International Review of Applied Psychology 29, 159-172.

[15] Feldman, C. \& Shen, M. (1971) Some language-related cognitive advantages of bilingual five-year olds. Journal of Genetic Psychology 118, 235-244.

[16] Gleason, J. (2005). The Development of language, Boston: Allyn and Bacon.

[17] Goldman, S., Reyes, M. \& Varnhagen, C. (1984). Understanding fables in first and second languages. NABE Journal 3, 35-66.

[18] Harley, T.A. (2008). The psychology of language. USA: Taylor \& Francis.

[19] Herdina, P., \& Jessner. U. (2002). A dynamic model of multilingualism: Perspectives of Change in Psycholinguistics. Clevedon: Multilingual Matters.

[20] Hoffman, C. (2001). Towards a description of trilingual competence. International Journal of Bilingualism 5 (1), 1-17.

[21] Hu, M., \& Nation, I.S.P. (2000). Vocabulary density and reading comprehension. Reading in a Foreign Language, 23 (1), $403-$ 430.

[22] Ianco-Worall, A.D. (1972). Bilingualism and cognitive development. Child Development 43, 1390-1400.

[23] Jesperson, O. (1922). Language. London: George Allen and Unwin.

[24] Keshavarz, M.H. (2004). The impact of bilinguality on the learning of English vocabulary as a foreign language (L3). Bilingual Education and Bilingualism, 7 (4), 295-302. 
[25] Klein, E.C. (1995). Second versus third language acquisition: Is there a difference? Language Learning 45 (3), $419-465$.

[26] Lambert, W.E. \& Tucker, G.R. (1972). Bilingual Education of Children: The St. Lambert Experiment. Rowley, MA: Newbury House.

[27] Laufer, B. (1997). The lexical plight in second language reading. Cambridge: Cambridge University Press.

[28] Lerea, L. \& Laporta, R. (1971). Vocabulary and pronunciation acquisition among bilinguals and monolinguals. Language and Speech 14, 293-300.

[29] Maghsoudi, M. (2006). The impact of bilinguality on pre-university students in English achievement. South Asian Language Review, XVI (2), 26-35.

[30] Maghsoudi, M. (2008). Learning English as a third language: a comparative study between Iranian and Indian bilinguals. South Asian Language Review, XVIII (1), 28-41

[31] Magiste, E. (1984). Learning a third language. Journal of Multilingual and Multicultural Development 5, 415-421.

[32] Malakoff, M. (1988). The effect of language of instruction on reasoning in bilingual children. Applied Linguistics 9, 17-38.

[33] Matlin, M.M. (1994). Cognition. USA: Ted Buchholz.

[34] Mattes, L. J. \& Omark, D. R. (1984). Speech and Language assessment for the Bilingual Handicapped. San Diego: College Hill Press.

[35] Meara, P. (1995). The importance of an early emphasis on L2 vocabulary. The Language Teacher, 19 (2), 8-10.

[36] Nation, I.S.P. (2001). Learning Vocabulary in Another Language. Cambridge: Cambridge University Press.

[37] Nayak, H., Hansen, N., Krueger, N. \& Mclaughlin, B. (1990). Language-learning strategies in monolingual and multilingual adults. Language Learning 40, 221-244.

[38] Printer, R. \& Keller, R. (1922). Intelligence tests for foreign children. Journal of Educational Psychology, 13, 1-23.

[39] Reich, R. (1978). Gestural facilitation of expressive language in moderately/severely retarded preschoolers. Mental Retardation, 16 (2), 113-117.

[40] Richards, J. C. \& Renandya W. A. (2002). Methodology in Language Teaching: An Anthology of Current Practice. United States of America: Cambridge University Press

[41] Ringbom, H. (1985). Foreign language learning and bilingualism. Turku: Abo Akademi.

[42] Saer, O.J. (1923). The effect of bilingualism on intelligence. British Journal of Psychology 14, 25-28.

[43] Sanz, C. (2000). Bilingual education enhances third language acquisition: Evidence from Catalonia. Applied Psycholinguistics $21(1), 23-44$.

[44] Segalowitz, N. (1977). Psychological perspectives on bilingual education. In B. Spolsky and R. Cooper (Eds.) Frontiers of Bilingual Education (pp. 119-158). Rowley, MA: Newbury House.

[45] Thomas, J. (1988). The role played by metalinguistic awareness in second and third language learning. Journal of Multilingual and Multicultural Development 9, 235-247.

[46] Trask, R.L. (1999). The Key Concepts in Language and Linguistics. New York: Routledge.

[47] Valencia, J.F. \& Cenoz, J. (1992). The role of bilingualism in foreign language acquisition. Journal of Multilingual and Multicultural Development 13 (5), 433-446.

[48] Vermeer, A. (2001). Breadth and depth of vocabulary in relation to L1/L2 acquisition and frequency of Input Applied Psycholinguistics, 22(2), 217-234.

[49] Zobl, H. (1993). Prior linguistic knowledge and the conservation of the learning procedure: Grammaticality judgements of unilingual and multilingual learners. In S.M. Gass and L. Selinker (Eds.) Language Transfer in Language Learning (pp. 176196). Amsterdam: John Benjamins.

Zohreh Kassaian holds a PhD in TEFL. She is an assistant professor in Isfahan University, Iran and has taught English to EFL students for 31 years. Her research interests are psycholinguistic studies and genre analysis.

Saeedeh Esmae'li is an MA student in TEFL at the University of Isfahan. She has taught English courses in different institutes in Iran. Her main research interests are Language teaching and assessment and Second language acquisition. 